TELAGA BAHASA

Volume 5

No. 2 Desember 2017

Halaman 279-296

\title{
RANAH PENGGUNAAN BAHASA JAWA OLEH KALANGAN KELUARGA MUDA DI EKS KARASIDENAN SEMARANG
}

\author{
(The Areas of Javanese Use among Young Married Couples \\ in Ex-Karesidenan Semarang)
}

\section{Retno Hendrastuti}

Balai Bahasa Jawa Tengah

Jalan Elang Raya Nomor 1, Mangunharjo, Tembalang, Semarang

Pos-el: retnohendras@gail.com

\begin{abstract}
Abstrak
Akhir-akhir ini muncul kekhawatiran terhadap keberadaan bahasa Jawa karena berkurangnya penggunaan bahasa Jawa untuk komunikasi. Penelitian ini menggunakan pendekatan campuran kualitatif dan kuantitatif untuk mendapatkan gambaran ranah-ranah penggunaan bahasa Jawa di kalangan keluarga muda di eks-Karesidenan Semarang serta alasannya. Hasil penelitian menunjukkan bahwa penggunaan bahasa Jawa di kalangan keluarga muda di eks-Karesidenan Semarang meliputi enam ranah kehidupan sosial, yaitu ranah keluarga, tetangga, pekerjaan, pertemanan, jual beli, dan tempat umum. Adapun alasan-alasan penggunaan bahasa Jawa tersebut adalah anggota masyarakat tersebut mayoritas merupakan penduduk asli Jawa; sudah biasa digunakan dan dikenal sejak kecil; untuk menciptakan hubungan dekat, hangat, dan tidak formal; upaya memberikan pelajaran dan contoh bahasa bagi anak dan orang bukan sesuku, sebagai ekspresi kesopanan dan penghormatan, untuk menghilangkan rasa canggung dan berlebihan apabila menggunakan bahasa Indonesia, serta agar komunikasi lebih mudah dipahami.
\end{abstract}

Kata Kunci: ranah, bahasa Jawa, keluarga muda, eks-Karesidenan Semarang.

\section{Abstract}

The Javanese language is one of the Indonesian local languages with the largest speakers. Meanwhile, there is anxiety that has been rise lately about the existence of Javanese language since the use of it in communication had been drastically decreased. This research uses mixed methods of qualitative and quantitative to obtain the areas and reasons why the Javanese language had been used among young married couples in ex-Semarang regency. The 
result of the study showed that the use of Javanese language found in six areas; familyhood, neighborhood, working area, friendship, trading area, and public space. The reasons of the using of Javanese language is simply because the majority of the society were native speakers; so it has been commonly using since early age; to develop warm and unformal relationship; to give language lesson and example to children and to other people; the expression of politeness and honors; to eliminate awkward and overact feeling when use Indonesian language, so that the communication would be easier to understand.

Keywords: areas, Javanese, young married couples, ex-Karesidenan Semarang

\section{PENDAHULUAN}

Ketika berinteraksi dengan orang lain, seringkali seseorang dihadapkan dengan pilihan beberapa jenis bahasa yang dapat digunakan. Artinya, mereka menjadi bagian dari sebuah komunitas atau kelompok masyarakat tutur bilingual atau multilingual, yaitu seseorang dapat berbicara dalam dua bahasa atau lebih. Pada kondisi seperti tersebut, mereka harus memilih atau menentukan sikap terhadap bahasa yang akan digunakan saat berinteraksi dengan orang lain.

Bahasa Jawa merupakan salah satu bahasa daerah di Indonesia yang dihadapkan dengan situasi bilingualisme. Sebagai bahasa ibu, bahasa Jawa digunakan berdampingan dengan bahasa lain, seperti bahasa daerah yang lain, bahasa Indonesia, dan bahasa asing. Banyak penutur bahasa Jawa lebih memilih menggunakan bahasa lain dalam berkomunikasi. Kondisi tersebut memunculkan kekhawatiran terhadap keberadaan bahasa Jawa. Karena bagaimanapun bahasa Jawa merupakan identitas lokal atau jati diri masyarakat Jawa. Bahasa Jawa memiliki kekhasan dan ciri tersendiri yang membedakannya dengan bahasa lain.

Dewasa ini eksistensi bahasa Jawa mengalami kemunduran. Bahasa Jawa yang merupakan media komunikasi yang digunakan masyarakat Jawa sejak dulu, kini sudah mulai tidak digunakan sebagai bahasa tutur sehari-hari. Mundurnya penggunaan bahasa Jawa disebabkan adanya ancaman dari bahasa asing (bahasa Inggris) dan dari bahasa nasional (bahasa Indonesia). Banyak penutur bahasa Jawa lebih memilih menggunakan bahasa lain dalam berkomunikasi. Padahal, salah satu tanda lestarinya sebuah bahasa adalah tetap digunakannya bahasa tersebut untuk berkomunikasi dengan sesama penggunanya. 
Selain itu, turunnya penggunaan bahasa Jawa memberi dampak negatif bagi kondisi sosial masyarakatnya. Bahkan, berbagai tindak kekerasan, pertikaian antarkelompok, pemboman, perbedaan pendapat di tingkat atas, korupsi terselubung merupakan penggambaran situasi kacau balau bangsa yang salah satunya disebabkan oleh kealpaan penutur bahasa Jawa (Suharti, 2006).

Penggunaan bahasa Jawa merupakan fenomena yang menarik untuk dikaji. Kajian penggunaan bahasa Jawa dalam masyarakat Jawa berkaitan dengan permasalahan penggunaan bahasa Jawa dalam konteks masyarakat Jawa yang dwibahasa atau multibahasa. Situasi kebahasaan masyarakat Jawa sekurang-sekurangnya ditandai oleh penggunaan dua bahasa, yaitu bahasa daerah sebagai bahasa ibu dan bahasa Indonesia sebagai bahasa nasional. Penelitian ini bertujuan mengamati penggunaan bahasa Jawa di kalangan keluarga-keluarga muda di wilayah eks-Karesidenan Semarang pada ranah sosial. Wilayah ini meliputi Kabupaten Kendal, Kabupaten Semarang (Ungaran), Kota Salatiga, Kota Semarang, Kabupaten Demak, dan Kabupaten Grobogan. Keenam daerah tersebut memiliki area-area transisi yang banyak didatangi pendatang serta berbatasan langsung pusat kota Semarang.

Penelitian ini berkaitan dengan pemilihan bahasa Jawa oleh keluarga muda dalam interaksi sosial. Chaer (2010:154) mengemukakan pendapat Fasold yang menyebutkan bahwa penelitian terhadap pemilihan bahasa dapat dilakukan dengan tiga pendekatan, yaitu pendekatan psikologi sosial, pendekatan sosiologi, dan pendekatan antropologi. Pendekatan psikologi sosial memandang bahwa dalam memilih sebuah bahasa, seseorang tentunya dipengaruhi oleh faktor psikologis dalam diri penutur. Latar belakang kejiwaan, termasuk motivasi para penuturnya berpengaruh dalam pemilihan bahasa kelompok masyarakat Indonesia yang multilingual. Pendekatan sosiologi mengarah pada konteks institusional tertentu, seperti topik, lokasi, dan partisipan. Partisipan dapat berupa keluarga, tetangga, teman, transaksi, pemerintahan, pendidikan, pekerjaan, dan sebagainya. Pendekatan antropologi mengkaji proses antropologi suatu kelompok masyarakat yang memiliki kebudayaan yang sama. Dengan demikian, akan terlihat jelas hal-hal yang memengaruhi individu dalam suatu kelompok masyarakat untuk memilih suatu bahasa tertentu. Penelitian ini cenderung menggunakan pendekatan sosiologi dan pendekatan antropologi, terutama untuk menggali faktor-faktor atau alasan pemilihan bahasa Jawa oleh kalangan kelarga muda di eks-Karesidenan Semarang. 


\section{TEORI}

Dalam interaksi sehari-hari antar anggota masyarakat menggunakan bahasa sebagai media komunikasinya. Bahasa merupakan media utama dalam komunikasi antara individu-individu dalam masyarakat, seperti keluarga, teman, kolega di tempat kerja, dan lain-lain (Turner\&West, 2008: 105-107). Artinya, melalui bahasa, manusia dapat bertukar informasi dengan orang lain.

Ketika berinteraksi dengan anggota masyarakat yang berbeda seorang seringkali harus memilih beberapa jenis bahasa yang berbeda pula. Pemilihan bahasa dipengaruhi oleh beberapa faktor sosial. Holmes (2001:21) mengungkapkan beberapa faktor sosial yang memengaruhi pilihan bashasa seseorang, antara lain topik pembicaraan, lawan bicara, dan konteks sosial dari pembicaraan. Selain itu, Holmes (2001:2526) juga mengungkapkan faktor lain yang dapat berpengaruh pada pemilihan bahasa. Faktor tersebut terkait dengan faktor lawan bicara, yaitu jarak sosial, hubungan sosial, tingkat keformalan, serta maksud pembicaraan.

Bahasa ibu sering digunakan ketika berinteraksi dengan sesama anggota masyarakat bahasanya. Bahasa ibu merupakan bahasa pertama yang dikuasai seseorang sejak awal hidupnya. Bahasa ibu digunakan oleh orang dewasa pada saat berbicara dengan anak yang dalam masa memperoleh bahasa ibu (Dardjowidjojo, 2005:224). Proses ini berlangsung secara intuitif dan simultan tatkala seseorang mempelajari bahasa Ibunya. Bahasa ibu memiliki pola-pola ungkapan yang mapan, sistem gramatika, dan leksikon yang membentuk cara pandang, nilai-nilai yang berlaku dalam masyarakat bahasa dan budaya setempat (ㄱ ૧ Mahsun, 2001).

Bahasa Jawa merupakan bahasa ibu bagi suku Jawa. Keberadaannya ikut memperkaya keragaman budaya Indonesia diantara sekian banyak bahasa daerah di Indonesia. Bahasa Jawa memiliki kaidah yang berbeda dengan bahasa lainnya. Bahkan, bahasa Jawa memiliki aksara sendiri, yaitu aksara Jawa, Bahasa Jawa juga memiliki dialek yang berbeda dari tiap daerah, serta unggah-ungguh bahasa yang berbeda. Selain itu, bahasa Jawa merupakan salah satu bahasa daerah di Indonesia dengan penutur terbanyak di Indonesia. Bahasa Jawa merupakan bahasa yang dipakai di daerahdaerah Provinsi Jawa Tengah, DIY, dan Jawa Timur.

Era globalisasi memberi dampak negatif bagi bahasa Jawa. Hal tersebut ditunjukkan oleh jumlah penutur bahasa Jawa tinggal sedikit. Hal tersebut dibenarkan oleh sejumlah pakar budaya dan guru bahasa Jawa. Seperti pernyataan dosen Fakultas 
Bahasa dan Seni Universitas Negeri mempertahankan bahasa daerah, (6) bencana Yogyakarta (UNY), Sri Harti Widyastuti alam dan musibah memusnahkan penutur berikut. "Sekarang ini bahasa Jawa sebagai sebuah bahasa, (7) kurangnya penghargaan bahasa percakapan sehari-hari sudah terhadap bahasa etnik sendiri, (8) kurangnya ditinggalkan. Berdasarkan penelitian intensitas komunikasi berbahasa daerah menunjukkan banyak keluarga yang tidak dalam berbagai ranah khususnya dalam ranah lagi menggunakan bahasa Jawa sebagai rumah tangga, (9) faktor ekonomi bahasa ibu dalam kehidupan rumah mendorong orang untuk mempelajari dan tangganya.” (Kompas Regional, 2009).

menggunakan bahasa asing untuk

Berkurangnya penutur bahasa Jawa dipengaruhi oleh beberapa faktor. Menurut Purwo (2000:11) ada beberapa faktor yang menyebabkan bahasa menjadi punah selain karena globalisasi dan modernisasi, yaitu (1) penduduknya mati semua karena wabah, (2) ditinggalkan oleh penuturnya karena berpindah dari bahasa ibunya ke bahasa lain karena dipaksa, (3) penuturnya memilih pindah ke bahasa lain karena bahasa lain dianggap lebih maju dan modern, (4) penuturnya berjumlah di bawah 100.000, (5) mengajarkan bahasa non-ibu sebagai bahasa pendidikan. Pendapat tersebut senada dengan 10 faktor penyebab kepunahan bahasa yang disampaikan Tondo (2009), yaitu (1) pengaruh bahasa yang mayoritas digunakan, (2) kondisi masyarakat penuturnya yang bilingual atau multilingual, (3) pengaruh era globalisasi yang mendorong interaksi dengan penutur bahasa lain, (4) migrasi mendorong penggunaan bahasa setempat, (5) perkawinan antaretnik menciptakan kesulitan untuk memperoleh pekerjaan dan penghidupan yang lebih baik, (10) bahasa Indonesia sebagai bahasa resmi negara menggeser bahasa daerah. Pada konteks bahasa Jawa penyebab menurunnya penggunaan nya ditandai dengan penggunaan bahasa kedua, yaitu bahasa Indonesia dan bahasa Inggris. Bahasa Jawa mendapat ancaman dari kedua bahasa tersebut karena dianggap lebih maju dan modern.

Namun demikian, pada masyarakat Jawa bahasa Jawa masih banyak diujarkan, baik pada tataran wacana sampai hanya kosakatanya. Pada tataran wacana bahasa Jawa diujarkan dalam konteks komunikasi bahasa Jawa, sedangkan pada tataran kosakata diujarkan dalam konteks komunikasi bahasa Indonesia. penggunaan kosakata bahasa Jawa dalam bahasa Indonesia dilatarbelakangi oleh beberapa alasan, yaitu (1) bahasa Indonesia belum memiliki kosakata dengan makna seperti yang diharapkan oleh pembicara, 
keinginan dari pemakai bahasa untuk menunjukkan asal-usul daerahnya, dan (3) sebagai bentuk penghormatan kepada lawan bicara (seperti penyebutan gelar kebangsawanan: Ingkang sinuhun, Ngarso dalem, dll) (Pressanti, dkk., 2008: 2).

\section{METODE}

Penelitian ini bertujuan mengamati penggunaan bahasa Jawa di kalangan keluarga-keluarga muda di wilayah eksKaresidenan Semarang pada ranah tertentu. Keluarga muda dipilih sebagai sumber data karena berada pada rentang usia paling produktif serta memiliki akses komunikasi paling besar di berbagai ranah sosial. Kemudian, wilayah eks-Karesidenan Semarang dijadikan lokasi penelitian karena berada di perbatasan dengan kota Semarang yang merupakan pusat kota di Jawa Tengah. Artinya, kecenderungan untuk berkomunikasi dengan bahasa Jawa atau bahasa lainnya menarik untuk diteliti.

Penelitian ini menggunakan paduan metode kualitatif dan kuantitatif. Hal tersebut terlihat dari penggunaan paduan teknik pengumpulan data sampai teknik analisis data untuk mendapatkan jawaban atas permasalahan penelitian. Artinya, penelitian campuran seperti ini memadukan dua pendekatan dalam semua tahapan proses penelitian (Abbas \& Teddlie, 2010:viii).
Penelitian ini merupakan penelitian lapangan yang bersifat kualitatif-kuantitatif. Artinya, penelitian ini menggunakan metode campuran pendekatan kualitatif dan kuantitatif. Pemaduan ini terlihat dari teknik pengumpulan data sampai teknik analisis data untuk mendapatkan jawaban atas permasalahan penelitian. Artinya, memadukan dua pendekatan dalam semua tahapan proses penelitian (Sugiyono, 2013:404). Dalam memperoleh data penelitian ini juga menggunakan tahapan dengan 2 metode penelitian. Creswell (2010:317-318) menyatakan bahwa tahap pertama pada penelitian campuran adalah pengumpulan dan analisis data kualitatif yang dilanjutkan dengan pengumpulan dan analisis data kuantitatif. Penggabungan teknik analisis kuantitatif dan kualitatif bertujuan untuk memperoleh analisis yang lebih lengkap. Teknik ini dilakukan dengan mengidentifikasikan komponen konsep (subkonsep) melalui analisis data kuantitatif dan kemudian mengumpulkan data kualitatif guna memperluas informasi yang tersedia (Abbas \& Teddlie, 2010:222). Namun demikian, penelitian campuran ini lebih menekankan pada metode kualitatif (McMillan, 2010: 402). Disini, penelitian kualitatif digunakan untuk menetapkan fokus penelitian, memilih informan sebagai sumber data, melakukan pengumpulan data, menilai 
kualitas data, analisis data, menafsirkan data, dan membuat kesimpulan atas temuannya (Sugiyono, 2013:306).

Pada penelitian ini pengumpulan data dilakukan dengan menggunakan kuesioner serta wawancara. Melalui kuesioner, responden diminta untuk menjawab seputar bahasa yang mereka kuasai dan gunakan. Rekaman digunakan untuk menjaring data yang dapat memperjelas data yang diperoleh melalui kuesioner. Hasil wawancara dapat digunakan untuk melengkapi data yang diperoleh dari teknik-teknik yang lain. Responden dalam penelitian ini adalah 20 anggota pasangan muda yang tinggal di eksKaresidenan Semarang. Pasangan muda yang dimaksud adalah pasangan suami-istri yang telah menikah selama lima belas tahun atau kurang.

Dalam penelitian ini digunakan dua jenis data, yaitu kualitatif dan kuantitatif. Adapun data kuantitatif dalam penelitian ini adalah angka-angka yang menunjukkan jumlah dan prosentase jawaban responden yang menggali penggunaan bahasa Jawa pada situasi tertentu. Dari angka-angka tersebut dapat disimpulkan berapa banyak responden yang menggunakan bahasa Jawa pada ranah tertentu di kota atau kabupaten wilayah eks karesidenan Semarang. Kemudian, data kualitatif pada penelitian ini berupa pernyataan responden mengenai alasan digunakannya bahasa Jawa pada situasi tertentu serta data sekunder dari review-review tentang penggunaan bahasa Jawa di wilayah Jawa Tengah. Data-data tersebut dapat digunakan untuk mendeskripsikan di ranah manakah bahasa Jawa lebih dominan digunakan serta bagaimana dan mengapa hal tersebut dapat terjadi. Dengan demikian, untuk analisis data, peneliti menggunakan jenis penelitian deskriptif analisis, yaitu penelitian yang bertujuan memahami fenomena yang dialami oleh subyek penelitian, misalnya perilaku, persepsi, motivasi, tindakan (Moleong, 2010: 4).

\section{PEMBAHASAN}

Berdasarkan hasil temuan di lapangan, ranah penggunaan bahasa Jawa di kalangan keluarga muda di eks-Karesidenan Semarang meliputi ranah-ranah kehidupan sosial. Pada ranah-ranah tersebutlah kalangan keluarga muda di eks-Karesidenan menggunakan bahasa Jawa dalam komunikasi mereka sehari-hari. penggunaan bahasa Jawa di kalangan keluarga muda di eks-Karesidenan Semarang ditemukan dalam enam ranah kehidupan sosial, yaitu ranah keluarga, tetangga, pekerjaan, pertemanan, jual beli, dan tempat umum.

Penggunaan bahasa Jawa di kalangan keluarga muda di eks-Karesidenan Semarang 
pada ranah-ranah sosial dapat diperoleh dari hasil kajian jawaban 20 responden atas 25 butir pertanyaan. Pertanyaan yang dimaksud berupa pertanyaan tertutup dan terbuka terkait dengan penggunaan bahasa Jawa dalam komunikasi sehari-hari. Selanjutnya, dari hasil jawaban tersebut dapat dilihat di ranah apa bahasa Jawa dominan dipakai kalangan keluarga muda di eks-Karesidenan Semarang. penggunaan bahasa Jawa pada ranah tertentu yang dominan dapat dilihat dari jumlah responden yang menjawab menggunakan bahasa Jawa pada setiap pertanyaan. Selanjutnya, keseluruhan jawaban penggunaan bahasa Jawa setiap ranah dijumlahkan dan dibagi jumlah butir pertanyaan pada ranah tersebut untuk memperoleh rata-rata. Selain itu, hasil jumlah jawaban pertanyaan kuesioner dari setiap kabupaten atau kota juga digunakan untuk mengetahui dominasi penggunaan bahasa Jawa di kalangan keluarga muda di eksKaresidenan Semarang pada ranah tertentu. Berikut ini penjelasan lebih lanjut tentang penggunaan bahasa Jawa pada masingmasing ranah kehidupan sosial kalangan keluarga muda di eks-Karesidenan Semarang.

\section{Penggunaan Bahasa Jawa pada Ranah Keluarga}

Penggunaan bahasa Jawa pada ranah keluarga pada penelitian ini merupakan kajian terhadap bahasa Jawa sebagai sarana komunikasi kalangan keluarga muda di eksKaresidenan Semarang ketika berinteraksi dengan sesama anggota keluarga mereka. Penggunaan bahasa Jawa di kalangan keluarga muda di eks-Karesidenan Semarang pada ranah ini terlihat dari kajian hasil jawaban kalangan keluarga muda di eksKaresidenan Semarang ketika menjawab pertanyaan-pertanyaan seputar penggunaaan bahasa Jawa pada ranah keluarga. Pertanyaan-pertanyaan yang dimaksud meliputi penggunaan bahasa ketika berbicara dengan saudara, orang tua, mertua, anak, dan suami/istri di rumah.

Temuan penelitian ini menunjukkan bahwa pada ranah keluarga penggunaan bahasa Jawa dengan prosentase tertinggi digunakan responden dengan saudara dan orang tua $(88,3 \%)$. Bahasa Jawa digunakan responden ketika berkomunikasi dengan kedua anggota keluargaanya tersebut baik ketika di dalam atau di luar rumah. Adapun alasan-alasan penggunaan bahasa Jawa tersebut antara lain adalah karena bahasa Jawa sudah biasa digunakan dan diajarkan sejak kecil dan bahasa Jawa digunakan untuk 
menciptakan hubungan dekat, hangat, dan tidak formal.

Setelah itu, penggunaan bahasa Jawa yang cukup signifikan juga terlihat ketika mereka berkomunikasi dengan suami atau istri dan juga mertua $(81,7 \%$ dan $84,2 \%)$. Penggunaan bahasa Jawa dengan suami atau istri juga dipengaruhi oleh faktor kebiasaan dari kecil dan upaya memberikan contoh kepada anak. Penggunaan bahasa Jawa dengan mertua cenderung sebagai sarana kesopanan dan penghormatan, terutama dengan menggunakan bahasa Jawa halus.

Kemudian, pada ranah keluarga penggunaan bahasa Jawa dengan prosentase terendah terlihat pada saat responden berkomunikasi dengan anak $(68,3 \%)$. Hal ini disebabkan pengaruh era modernisasi dan globalisasi yang menuntut penguasaan bahasa Indonesia dan bahasa Inggris untuk menambah pengetahuan.

Penggunaan Bahasa Jawa pada Ranah Tetangga

Penggunaan bahasa Jawa di kalangan keluarga muda di eks-Karesidenan Semarang pada ranah tetangga meliputi penggunaan bahasa Jawa yang digunakan masyarakat keenam kabupaten dan kota eks-Karesidenan Semarang dalam berkomunikasi dengan tetangga. Pada penelitian ini pertanyaanpertanyaan yang digunakan untuk mengetahui penggunaan bahasa Jawa di kalangan keluarga muda di eks-Karesidenan Semarang pada ranah tetangga meliputi bahasa yang digunakan ketika berbicara dengan tetangga sesuku, dengan tetangga tidak sesuku, dan dalam rapat RT/RW.

Pada ranah tetangga penggunaan bahasa Jawa tertinggi terlihat ketika responden harus berbicara dengan tetangga sesuku (Jawa) (89,2\%). Hal ini berkaitan dengan kebiasaan serta upaya menciptakan kemudahan dalam berkomunikasi serta menjaga keakraban antaranggota masyarakat. Selain itu, pada ranah tetangga penggunaan bahasa Jawa juga secara signifikan terlihat ketika para responden berkumpul dengan tetangga pada acara perkumpulan RT atau RW (58\%). Hal ini disebabkan anggota masyarakat tersebut mayoritas merupakan penduduk asli Jawa. Selanjutnya pada ranah tetangga penggunaan bahasa Jawa terendah dapat dilihat dari penggunaan bahasa Jawa kepada tetangga beda suku, yaitu 9,2\%. Fenomena tersebut terjadi karena tidak semua penduduk di wilayah tersebut berlatar belakang dari suku yang sama.

\section{Penggunaan Bahasa Jawa pada Ranah Pekerjaan}

Penggunaan bahasa Jawa pada ranah pekerjaaan pada penelitian ini meliputi penggunaan bahasa Jawa pada saat 
responden berkomunikasi dengan teman kerja. Untuk mengetahui bahasa Jawa di kalangan keluarga muda di eks-Karesidenan Semarang pada ranah ini digunakan pertanyaan-pertanyaan yang terdiri atas informasi penggunaan bahasa saat berbicara dengan teman kerja sesuku dan teman kerja tidak sesuku di lingkungan kerja.

Dari hasil penelitian dapat terlihat adanya perbedaan yang signifikan dalam jawaban penggunaan bahasa Jawa pada ranah pekerjaan. Penggunaan bahasa Jawa yang cukup tinggi terlihat pada bahasa Jawa untuk alat komunikasi dengan teman sesuku $(71,7 \%)$. Adapun alasan yang disampaikan untuk penggunaan bahasa Jawa ini adalah adanya perasaan lebih nyaman dan akrab saat berkomunikasi serta menghilangkan rasa canggung dan berlebihan apabila menggunakan bahasa Indonesia. Sebaliknya, hanya sedikit yang menggunakan bahasa Jawa saat berkomunikasi dengan teman kerja bukan sesuku (11,7\%). Bahasa Jawa tetap digunakan karena faktor ketidaksengaaan terkait kebiasaan menggunakan bahasa Jawa dalam keseharian mereka. Namun, bahasa Jawa terkadang sengaja digunakan untuk mengenalkan dan membiasakan tetangga dari suku lain agar belajar bahasa Jawa.

\section{Penggunaan Bahasa Jawa pada Ranah Pertemanan}

Pada penelitian ini, penggunaan bahasa Jawa pada ranah pertemanan diperoleh melalui jawaban kuesioner yang menyatakan penggunaan bahasa Jawa saat berinteraksi dengan teman. Pertanyaanpertanyaan dalam ranah pertemanan ini memiliki variasi cukup signifikan, yaitu berdasarkan usia, suku, serta lokasi. Pertanyaan-pertanyaan yang dimaksud meliputi penggunaan bahasa dengan teman sebaya, lebih tua, dan lebih muda, baik yang sesuku dan tidak sesuku.

Pada penelitian ini, penggunaan bahasa Jawa pada ranah pertemanan yang didominasi oleh bahasa Jawa sebagai alat komunikasi dengan teman sesuku, baik yang lebih tua maupun lebih muda $(83,3 \%)$. Ini terkait dengan alasan perasaan lebih nyaman dan akrab saat berkomunikasi dengan menggunakan bahasa Jawa. Selain itu, penggunaan bahasa Jawa pada ranah pertemanan yang cukup tinggi terlihat pada komunikasi dengan teman sesuku diperantauan $(66,7 \%)$, teman anak $(71,7 \%)$, dan teman suami atau istri $(76,7 \%)$. Ini juga untuk menjaga keakraban antarteman sesuku. Kemudian, penggunaan bahasa Jawa pada ranah pertemanan menunjukkan prosentase yang rendah ketika responden harus berkomunikasi dengan teman bukan sesuku, 
baik teman yang lebih tua $(12,5 \%)$ atau lebih muda $(10,8 \%)$, teman anak $(11,7 \%)$, dan teman suami, atau istri $(8,3 \%)$. Penggunaan bahasa Jawa tersebut sengaja dilakukan karena lawan bicara mereka sudah lama menetap di lingkungan mereka dan dapat memahami maksud pembicaraan mereka meskipun mereka menggunakan bahasa Jawa.

Penggunaan Bahasa Jawa pada Ranah Jual Beli

Ranah jual beli juga menjadi ranah yang didapati adanya penggunaan bahasa Jawa. Pada penelitian ini penggunaan bahasa Jawa pada ranah jual beli dibedakan berdasarkan perbedaan tempat dan suku. Pertanyaan-pertanyaan yang digunakan meliputi penggunaan bahasa saat berbelanja di tempat orang yang dikenali sesuku dan tidak sesuku serta berbelanja di tempat orang yang tidak dikenali.

Dari angka-angka tabel di atas dapat disimpulkan bahwa pada ranah jual beli penggunaan bahasa Jawa dominan digunakan ketika berinteraksi jual beli dengan orang sesuku, baik di warung (85\%) maupun di pasar (86\%). Adapun alasan penggunaan bahasa Jawa ini adalah untuk mebangun keakraban dan kedekatan dan memperoleh harga termurah ketika harus menawar. Pada urutan berikutnya penggunaan bahasa Jawa juga ditemukan ketika responden tidak mengenal lawan tuturnya $(50,8 \%)$. Pada urutan terakhir penggunaan bahasa jawa terendah terlihat ketika responden harus berkomunikasi dengan penjual yang bukan sesuku $(11,7 \%)$. Keduanya disebabkan anggapan bahwa lawan bicaranya tersebut berasal dari suku Jawa juga. Setelah itu, mereka langsung mengubah menggunakan bahasa Indonesia ketika mereka menyadari bahwa lawan bicaranya bukan dari suku Jawa.

\section{Penggunaan Bahasa Jawa pada Ranah Tempat Umum}

Penggunaan bahasa Jawa pada ranah umum merupakan ranah yang melibatkan interaksi berbahasa Jawa dengan orang lain di tempat umum. Pada penelitian ini komunikasi dibedakan berdasarkan perbedaan suku dan tempat. Adapun pertanyaan yang digunakan untuk mengetahui bahasa Jawa di kalangan keluarga muda di eks-Karesidenan Semarang pada ranah tempat umum menggali penggunaan bahasa jika responden berbicara dengan orang yang sesuku, tidak sesuku, petugas pelayanan umum, pengemudi atau kernet angkutan umum.

Penggunaan bahasa Jawa tertinggi terlihat pada komunikasi dengan orang sesuku menggunakan bahasa Jawa, yaitu 
$84,2 \%$. Dengan berbahasa Jawa komunikasi akan lebih akrab dan efektif. Berikutnya, komunikasi dengan pengemudi atau kernet angkutan umum menduduki posisi kedua, yaitu $69,2 \%$. Hal ini terjadi karena mereka yakin jika semua pengemudi atau kernet angkutan umum di wilayah mereka berasal dari suku Jawa, sehingga komunikasi akan lebih mudah dipahami jika berbahasa Jawa.

Selanjutnya, di ranah umum, penggunaan bahasa Jawa saat komunikasi dengan petugas pelayanan umum berada di peringkat ketiga, yaitu $12,5 \%$. Penggunaan bahasa Jawa jarang ada karena petugas pelayanan umum lebih cenderung menggunakan bahasa Indonesia saat berkomunikasi dengan mereka. Bahasa Jawa hanya digunakan ketika melayani orang tua dan orang yang sudah mereka kenal dan akrab. Kemudian, penggunaan bahasa Jawa di ranah umum yang terendah terlihat pada komunikasi dengan orang bukan sesuku, yaitu 5\%. Penggunaan bahasa Jawa langsung diubah menjadi bahasa Indonesia ketika mereka menyadari bahwa lawan bicaranya bukan dari suku Jawa.

Penggunaan Bahasa Jawa di Kalangan Keluarga Muda di Eks-Karesidenan Semarang

Berdasarkan hasil rekapitulasi penggunaan bahasa Jawa di setiap kabupaten dan kota di eks-Karesidenan Semarang serta pada ranah sosial dapat terlihat. Berikut ini prosentase sebaran penggunaan bahasa Jawa pada setiap kabupaten dan kota di wilayah eks-Karesidenan Semarang pada setiap ranah.

\begin{tabular}{|l|l|l|l|l|l|l|l|l|}
\hline No. & Kab/Kota & \multirow{2}{*}{ KNDL } & GROB & UNG & SLTG & DMK & SMG & $\sum$ \\
\hline 1. & Keluarga & 94 & 84 & 66 & 86 & 82 & 81 & 82,2 \\
\hline 2. & Tetangga & 51,7 & 55 & 43,3 & 58,3 & 53,3 & 51,7 & 52,2 \\
\hline 3. & Pekerjaan & 40 & 40 & 35 & 42,5 & 50 & 42,5 & 41,7 \\
\hline 4. & Pertemanan & 46,1 & 45,6 & 41,7 & 45,6 & 52,2 & 52,2 & 47,2 \\
\hline 5. & Jual Beli & 70 & 51,3 & 52,5 & 52,5 & 62,5 & 62,5 & 58,5 \\
\hline 6. & $\begin{array}{l}\text { Tempat } \\
\text { Umum }\end{array}$ & 46,3 & 38,8 & 31,3 & 40 & 47,5 & 52,5 & 42,7 \\
\hline$\sum$ & & 58 & 52,5 & 45 & 54,2 & 57,9 & 57,1 & 54,1 \\
\hline
\end{tabular}


Dari angka-angka yang menunjukkan rata-rata frekuensi penggunaan bahasa Jawa, dapat terlihat dominasi penggunaan bahasa Jawa pada ranah tertentu di kalangan keluarga muda di eks-Karesidenan Semarang. Berdasarkan tabel di atas dapat terlihat bahwa dominasi penggunaan bahasa Jawa di kalangan keluarga muda di eksKaresidenan Semarang ada pada ranah keluarga $(82,2 \%)$, diikuti ranah jual beli $(58,5 \%)$, tetangga $(52,2 \%)$, pertemanan $(47,2 \%)$, tempat umum $(42,7 \%)$, dan terakhir ranah pekerjaan $(41,7 \%)$. Dominasi tersebut dapat dilihat dari frekuensi jawaban responden untuk memilih jawaban bahasa Jawa pada pertanyaan-pertanyaan tentang penggunaan bahasa Jawa.

Selanjutnya, pada setiap kabupaten dan kota dapat diketahui pula dominasi dan kurangnya penggunaan bahasa Jawa pada ranah tertentu. Dari angka-angka yang menunjukkan rata-rata frekuensi penggunaan bahasa Jawa pada tabel di atas dapat terlihat bahwa di seluruh kabupaten dan kota eksKaresidenan Semarang ranah kelurga juga merupakan ranah tertinggi yang menunjukkan penggunaan bahasa Jawa sebagai bahasa komunikasi. Pada urutan kedua ada ranah jual beli yang menggunakan bahasa Jawa sebagai alat komunikasi masyarakat di wilayah eks-Karesidenan Semarang. Namun demikian, pada urutan ketiga dan seterusnya ada perbedaan. Lebih lanjut, penggunaan bahasa Jawa terendah ada perbedaan terlihat pada dua kelompok kabupaten dan kota. Di kelompok pertama ada Kabupaten Kendal dan Kota Semarang yang menunjukkan penggunaan bahasa Jawa terendah ada pada ranah pekerjaan. Kemudian, di kelompok kedua ada Kabupaten Grobogan, Ungaran, Salatiga, dan Demak yang menunjukkan penggunaan bahasa Jawa terendah pada ranah tempat umum. Secara keseluruhan ranah keluarga menjadi ranah tertinggi untuk penggunaan bahasa Jawa tertinggi di kalangan keluarga muda di eks-Karesidenan Semarang.

Penggunaan bahasa Jawa tertinggi pada ranah keluarga di kalangan keluarga muda di eks-Karesidenan Semarang dipengaruhi oleh beberapa hal. Salah satu alasan utama yang sesuai dengan hasil temuan di lapangan adalah bahwa dalam ranah keluarga bahasa Jawa cenderung berfungsi sebagai bahasa ibu. Dengan demikian, bahasa Jawa lebih sering digunakan daripada bahasa Indonesia. Selain itu, di dalam ranah keluarga, faktor usia dan jenis kelamin mempengaruhi penggunaan bahasa Jawa. Ada kecenderungan semakin 
muda usia penutur jati bahasa Jawa penggunaan bahasa Jawanya semakin banyak bercampur dengan bahasa Indonesia. Kemudian, penggunaan bahasa Jawa oleh perempuan lebih banyak dibandingkan dengan penggunaan bahasa Jawa oleh lakilaki. Hal ini disebabkan perempuan lebih banyak mendapat kesempatan untuk berkomunikasi dan mengajarkan bahasa Jawa kepada anak-anaknya.

Kemudian, ranah pekerjaan merupakan ranah terendah untuk penggunaan bahasa Jawa di kalangan keluarga muda di eks-Karesidenan Semarang. Hal ini sesuai dengan yang diungkapkan Widodo (2001) bahwa dalam ranah pekerjaan kemungkinan digunakannya bahasa Jawa sangat rendah. Lebih lanjut dia menyatakan bahwa pemilihan bahasa di dalam ranah pekerjaan siapa yang diajak berkomunikasi menentukan penggunaan bahasa Jawa dan bahasa Indonesia. Jika yang diajak bicara adalah atasan ataupun bawahan, ternyata bahasa Jawa dan bahasa Indonesia digunakan secara seimbang. Kemudian, jika yang diajak bicara adalah teman sejawat, pilihannya di antara lebih sering bahasa Jawa daripada bahasa Indonesia dan bahasa Jawa dan bahasa Indonesia sama seringnya, tetapi cenderung menggunakan bahasa Jawa dan bahasa Indonesia sama seringnya. Namun, ada kemungkinan bahwa penggunaan bahasa
Jawa dan bahasa Indonesia berimbang. Hal ini disebabkan dalam ranah pekerjaan ada tuntutan untuk menggunakan bahasa formal. Seperti diketahui bahwa dalam masyarakat bahasa formal yang digunakan dalam situai resmi adalah bahasa Indonesia.

Selanjutnya, berdasarkan tabel di atas dapat terlihat hampir samanya prosentase penggunaan bahasa Jawa pada setiap kabupaten dan kota. Namun demikian, penggunaan bahasa Jawa tertinggi terlihat pada Kabupaten Kendal, yaitu 58\%. Kemudian ada Kabupaten Demak, Semarang, Salatiga, dan Grobogan pada urutan berikutnya, yaitu $57,9 \%, 57,1 \%, 54,2 \%$, dan $52,5 \%$. Terakhir, pada urutan terendah penggunaan bahasa Jawa terlihat di Ungaran, yaitu 45\%. Secara keseluruhan, 54\% kalangan keluarga muda di eks-karesidenan Semarang menggunakan bahasa Jawa daripada bahasa lainnya, yaitu bahasa Indonesia. Artinya, penggunaan bahasa Jawa dan bahasa Indonesia di kalangan keluarga muda di eks-Karesidenan Semarang hampir seimbang.

Namun demikian, bahasa Jawa dan bahasa Indonesia tetap digunakan di seluruh lini kehidupan sosial keluarga muda di eksKaresidenan Semarang. Ada beberapa faktor yang menyebabkan hampir seimbangnya penggunaan bahasa Jawa dan bahasa Indonesia di kalangan keluarga muda di eks- 
Karesidenan Semarang. Seperti diketahui bahwa sebagian besar kalangan keluarga muda di eks-Karesidenan Semarang adalah dwibahasawan bahasa Jawa dan bahasa Indonesia. Artinya, sebagai dwibahasawan mereka berkomunikasi dengan bahasa Jawa dan bahasa Indonesia. Pemilihan penggunaan bahasa Jawa atau bahasa Indonesia oleh kalangan keluarga muda di eks-Karesidenan Semarang bergantung pada penguasaan kedua bahasa tersebut. Misalnya, di Kabupaten Semarang atau Ungaran yang merupakan kabupaten terendah untuk penggunaan bahasa Jawa. Faktor usia dan heterogenitas masyarakat Ungaran menyebabkan rendahnya penguasaan bahasa Jawa. Di samping itu, pemilihan penggunaan bahasa oleh kalangan keluarga muda di eksKaresidenan Semarang lebih banyak ditentukan oleh faktor-faktor luar bahasa, seperti siapa yang diajak bicara, di mana tempatnya, untuk tujuan apa, apa yang dibicarakan, dan lain-lain. Artinya, bahasa Jawa dan bahasa Indonesia digunakan sesuai dengan situasi yang menuntut digunakannya salah satu dari bahasa Jawa dan bahasa Indonesia (Widodo, 2001).

\section{PENUTUP}

Penggunaan bahasa Jawa di kalangan keluarga muda di eks-Karesidenan Semarang ditemukan dalam enam ranah kehidupan sosial, yaitu ranah keluarga $(82,2 \%)$, diikuti ranah jual beli $(58,5 \%)$, tetangga $(52,2 \%)$, pertemanan $(47,2 \%)$, tempat umum $(42,7 \%)$, dan terakhir ranah pekerjaan $(41,7 \%)$. Adapun alasan-alasan penggunaan bahasa Jawa tersebut antara lain adalah anggota masyarakat tersebut mayoritas merupakan penduduk asli Jawa, bahasa Jawa sudah biasa digunakan dan diajarkan sejak kecil, untuk menciptakan hubungan dekat, akrab, hangat, dan tidak formal, upaya memberikan contoh dan mengajari anak dan orang bukan sesuku, sebagai ekspresi kesopanan dan penghormatan, menghilangkan rasa canggung dan berlebihan apabila menggunakan bahasa Indonesia, serta komunikasi lebih mudah dipahami.

Kajian ini difokuskan pada penggalian ranah penggunaan bahasa Jawa serta alasannya pada keluarga muda di eksKaresidenan Semarang dengan menggunakan tenik kuesioner dan wawancara. Penggalian lebih lanjut melalui teknik observasi atau pengamatan perlu dilakukan, terutama untuk mengetahui secara langsung konteks situasi dan budaya serta unsur-unsur kebahasaan yang menandai. 


\section{DAFTAR PUSTAKA}

Abbas, T. \& Teddlie, C. 2010. Mixed Methodology: Mengkombinasikan Kualitatif dan Kuantitatif. Yogyakarta: Pustaka Pelajar.

Chaer, A. 2010. Sosiolinguistik Perkenalan Awal. Jakarta: Rineka Cipta.

Creswell, J. W. 2010. Research Design: Pendekatan Kualitatif, Kuantitatif, dan Mixed. Yogyakarta: Pustaka Pelajar.

Dardjowidjojo, S. 2003. Psikolinguistik: Pengantar Pemahaman Bahasa Manusia. Jakarta: Yayasan Obor Indonesia,

Kompas. 2009. Memprihatinkan, Nasib Penggunaan Bahasa Jawa. http://tekno.kompas.com/read/2009/0 5/17/06032772/memprihatinkan.nasi b.penggunaan.bahasa.jawa Diunduh pada 15 Juli 2017 pukul 13:00 WIB.

Holmes, J. 2001. An Introduction to Sociolinguistics. New York: Longman.

Mahsun. 2001. "Peran Bahasa Ibu dalam Membangun Kebudayaan Daerah". Makalah Musakarah Reaq Adat Tanaq Samawa, 25-26 Oktober 2001. Sumbawa.

Sumber: https://kemdikbud.go.id/dok umen/pdf/PERAN-BAHASA-IBUDALAM-MEMBANGUN-
KEBUDAYAAN-DERAH.pdf.

Diunduh pada 15 Juli 2017 pukul 14:00 WIB.

McMillan, J. H. \& Schumacher, S. 2010. Research in Education (EvidenceBased Inquiry) $7^{\text {th }}$ edition. New Jersey: Pearson Education inc.

Moleong, L. J. 2000. Metodologi penelitian kualitatif. Bandung: PT Remaja Rosdakarya.

Pressanti, dkk. 2008. Pemakaian Kosakata Bahasa Jawa dalam Bahasa Indonesia. Laporan Penelitian Tim. Balai Bahasa Semarang.

Purwo, K. B. 2000. Bangkitnya Kebhinekaan Dunia Linguistik dan Pendidikan. Jakarta: Mega Media Abadi.

Sugiyono. 2013. Metode Penelitian Kuantitatif, Kualitatif, dan $R \& D$. Bandung: Alfabeta.

Suharti. 2006. "Penerapan Unggah-Ungguh Berbahasa Jawa di Sekolah: Upaya Pembinaan Perilaku Bangsa yang Tangguh". Makalah. Kongres Bahasa Jawa IV, Semarang.

Tondo, F. H. 2009. Kepunahan BahasaBahasa Daerah: Faktor Penyebab dan Implikasi Etnolinguistis. Jurnal Masyarakat \& Budaya, Volume 11 No. 2. Hlm 277-295.

West, Richard \& Turner, L. H. 2008. Pengantar Teori Komunikasi: 
Analisis dan Aplikasi. Jakarta:

Salemba Humanika.

Widodo, S. 2001. Bahasa JawaSosiolinguistik. Tesis. Depok:

Universitas Indonesia.

Sumber:http://badanbahasa.kemdikbu

d.go.id/ lamanbahasa/ produk/1311.

Diunduh pada 15 Juli 2017 pukul 13:30 WIB. 
Telaga Bahasa, Vol. 5, No. 2, Desember 2017: 279-296 